\title{
381. Skiverletzungen - Verletzungsmuster, Ursachen, Prophylaxe
}

\author{
R. Ascherl, W. Hauser ${ }^{1}$, B. Müller ${ }^{2}$, E. Asang ${ }^{2}$, F. Lechner ${ }^{3}$ und G. Blümel \\ Institut für Experimentelle Chirurgie (Dir.: Prof. Dr. G. Blümel) der Technischen Universität München, \\ Ismaninger Straße 22, D-8000 München 80, \\ ${ }^{1}$ Technischer Überwachungsverein TÜV Bayern, \\ ${ }^{2}$ IAS-Internationaler Arbeitskreis Sicherheit beim Skilauf e. V. München (1. Vorsitzender: Prof. Dr. E. Asang) \\ und ${ }^{3}$ Kreiskrankenhaus Garmisch-Partenkirchen (Ärztl. Dir.: Prof. Dr. F. Lechner)
}

\begin{abstract}
Skiing Injuries - Pattem of Trauma, Causes and Prophylaxis
Summary. Statistical analysis of the pattern and frequency of injuries in alpine skiing demonstrates a significant decrease in formerly typical injuries. A controlled study still shows a high risk in the group of so-called A-skiers ( = beginners), female skiers and children. Severe injuries such as head injuries and multiple fractures of the tibia have increased. In the case of tibia fractures and knee injuries, an investigation of the adjustment of the release bindings shows values far in excess of the standards of the IAS. Thus, the importance of the IAS standards is emphasized.
\end{abstract}

Key words: Skiing injuries - Release-binding adjustment - Pattern of injury.

Zusammenfassung. Statistische Untersuchungen über Verletzungsmuster und Verletzungshäufigkeit beim alpinen Skilauf zeigen eine deutliche Abnahme der ehemals typischen Verletzungsformen. Eine kontrollierte Studie ergibt eine immer noch besonders hohe Gefährdung der sog. A-Fahrer (Anfänger), der kindlichen und weiblichen Skifahrer. Schwere Verletzungsformen wie Schädelhirntrauma oder Mehrfragmentbrüche der Tibia sind häufiger geworden. Eine Untersuchung über die Einstellwerte der Sicherheitsbindungen zeigt bei Tibiafrakturen und Kniebandläsionen gegenüber den Richtlinien der IAS fast ausnahmslos viel zu hohe Werte auf. Hierdurch wird der besondere Wert der IAS-Richtlinien zur Verletzungsprophylaxe unterstrichen.

Schliisselwörter: Skiverletzungen - Sicherheitsbindung - Einstellung - Verletzungsmuster.

\section{COLD - Ein System zur bettseitigen Messung des extravasalen Lungenwassers}

\author{
G. Blümel, G. Zimmermann, U. Pfeiffer, M. Birk ${ }^{1}$ und A. Heigl \\ Institut für Experimentelle Chirurgie der TU München (Dir.: Prof. Dr. G. Blümel), \\ Ismaninger Straße 22, D-8000 München 80, \\ ${ }^{1}$ Fa. Partig medical, Arabellastraße 15, D-8000 München 81
}

\section{COLD - a Device for the Bed-Side Quantification of Extravascular Lung}

Summary. A processor-controlled system is described that employs the "thermodye" dilution technique for the early detection of pulmonary edema in patients. Use of a 5-French catheter for the simultaneous detection of both the thermal and dye tracers in the descending aorta ensures essential improvements as regards the risks of bacterial contamination and the possibility of oxygen saturation measurement as compared to the prevalent intra-arterial and extracorporal split-detection techniques. Furthermore, the in situ tracer detection near the exit in combination with a system-controlled injection of the indicators, synchronized to definite circulatory and respiratory states, noticeably enhances the sensitivity and reproducibility of the method.

Key words: Pulmonary edema - ARDS - Thermo-dye-dilution technique.

Zusammenfassung. Es wird ein prozessor-gesteuertes System beschrieben, das in klinischer Anwendung des „Thermo-Dye"-Dilutons-Verfahrens die frühe Erfassung des Lungen-Ödems erlaubt. Die Verwendung eines $5 \mathrm{~F} \varnothing$-Katheters zur gleichzeitigen Messung beider Indikatoren in der A. desc. gewährleistet eine erhebliche Verringerung des bakteriellen Kontaminationsrisikos und eine Verbesserung bei zusätzlicher Messung der $\mathrm{O}_{2}$-Sättigung gegenüber der meist angewendeten Meßmethode mit Blutabzug. Zudem wird die Empfindlichkeit und Reproduzierbarkeit der Methode merklich erhöht durch die Verbindung der in-situ Messung mit einer prozessor-gesteuerten Indikatorinjektion zu einem genau definierten Zeitpunkt der Phasenlagen von Kreislauf und Atmung.

Schlïsselwörter: Lungenödem - ARDS - Thermo-Dye Technik. 